\title{
NORMALISED EATING AND DIETARY GUIDELINES IN LCHAD DEFICIENCY
}

\author{
MAEGORZATA RAJTAR \\ INSTITUTE OF PHILOSOPHY AND SOCIOLOGY \\ POLISH ACADEMY OF SCIENCES, WARSAW \\ \& HELSINKI COLLEGIUM FOR ADVANCED STUDIES, UNIVERSITY OF HELSINKI, FINLAND
}

Dietary guidelines have become a ubiquitous feature of nutritional landscapes in a growing number of countries. Issued by departments or ministries of health and implemented by dietitians and health professionals, such guidelines are intended to govern the health of children and adults by regulating both the content and quantity of what they eat. While these dietary guidelines are intended for kids and adults who can and want to eat, they often serve as a reference point for the dietary treatment of patients whose appetites are considered abnormal, and/or who do not or cannot eat. Drawing from ethnographic research being carried out in Finland and Poland on LCHADD, a rare disease, this article juxtaposes dietary treatments prescribed for this disease with state and biomedical rationalities that govern "normal" dietary patterns and normalised eating. Treatment for LCHADD differs from general dietary recommendations for "normal" growing children. Despite stringent dietary guidelines for LCHADD, dietitians admit that there are no global standards in place regulating the consumption of prescribed nutrients; thus, recommendations may vary by country.

Zasady dietetycznego odżywiania nieodłącznie wpisały się w krajobrazy żywienia coraz większej liczby krajów. Wydawane przez departamenty lub ministerstwa zdrowia zasady, wprowadzane następnie w życie przez dietetyków i profesjonalistów zajmujących się zdrowiem, mają na celu zarządzanie zdrowiem dzieci i dorosłych poprzez regulacje tego, co i w jakiej ilości spożywają. Zasady dietetycznego żywienia kierowane są do dzieci i dorosłych, którzy mogą i chcą jeść. Pomimo to, stanowią punkt odniesienia dla terapii dietetycznych pacjentów, których apetyt odbiega od normalnego i/lub którzy nie jedzą lub nie mogą jeść. W niniejszym artykule, opierając się na badaniach etnograficznych rzadkiej choroby, jaką jest niedobór LCHAD, w Finlandii i Polsce, zestawiam leczenie dietetyczne stosowane w tej chorobie z racjonalizacjami państwa i biomedycyny, które stoją za wzorcami „normalnego” żywienia i normalizacji jedzenia. Leczenie niedoboru LCHAD odbiega od ogólnych rekomendacji dietetycznych skierowanych do „normalnie” dorastających dzieci. Chociaż zasady odżywiania dietetycznego dla pacjentów z niedoborem LCHAD są bardzo restrykcyjne, dietetycy przyznają, że brakuje globalnych standardów lub norm, które regulowałyby konsumpcję składników odżywczych. W rezultacie rekomendacje mogą odbiegać od siebie w różnych krajach.

Ke y w o rd s: dietary guidelines, standardisation, food, rare diseases. LCHADD, Finland, Poland 


\section{INTRODUCTION $^{1}$}

During our discussions of food and nutrient related issues, Dr. Aurinko ${ }^{2}$, a dietitian working with LCHADD children (Long-Chain 3-Hydroxyacyl-CoA Dehydrogenase Deficiency) at one of the university hospitals in Finland, often consulted a large volume titled Clinical Paediatric Dietetics (Shaw, ed., 20I5). Along with her desktop computer, mountains of documents, bookshelves overwhelmed with literature and boxes laden with medicinal products, the volume was part and parcel of that spacious, well-lit and child-friendly university hospital office. As it turned out, the volume, which Dr. Aurinko virtually treated as the "bible" of metabolic diseases, enumerated dietary treatments for a large number of disorders. Written by UK based dietitians, it presented concise and universally applied dietary knowledge. But just how "universal" and "scientific" are the dietary guidelines recommended in this volume? And how are they implemented and contested in practice?

This article draws from research being carried out by three researchers among patients with LCHADD, their family members, physicians and members of patient advocacy associations in Poland and Finland since 2016 $6^{3}$. Along with participant observation at patients' homes, culinary workshops and conferences on rare disorders in Poland, illness narratives and life history interviews were conducted with 2I and 6 patients and/or families in Poland and Finland respectively. Additionally, semi-structured interviews with 9 and 7 medical professionals (physicians, dietitians, geneticists, a psychologist and a speech therapist) were carried out in Poland and Finland respectively. Moreover, a few members of patient advocacy associations were interviewed

I Acknowledgements: An earlier version of this article was presented at the American Anthropological Association Annual Meeting in Washington, D. C. I would like to thank the discussants of the panel "Normalization as Polemics", Aditya Bharadwaj and Kenneth T. MacLeish, for their insightful comments on my paper. I also would like to thank the anonymous reviewers and the editor of Ethnologia Polona for their comments as well as Anna Kwaśniewska and Anna Chowaniec-Rylke for their cooperation on and contribution to this research project, and Jake Heida for his help with editing and translations. Although this article is mainly based on grant research funded by the National Science Centre in Poland (Grant No. 2015/17/B/HS3/oolo7), the writing of this article was partly enabled by the EURIAS Fellowship Programme and the European Commission (Marie-Sklodowska-Curie Actions - COFUND Programme - $\mathrm{FP}_{7}$ ). I am particularly grateful to all research participants in Finland and Poland who shared their time, thoughts and experiences with us.

2 All names of the interviewees have been anonymised; additionally, age and gender details pertaining to patients with LCHADD have been altered to protect their privacy. Interviewees gave their verbal consent to participate in the research project. The majority of interviews were audio-recorded and transcribed.

3 The project titled "Socio-Cultural Dimensions of Rare Diseases: The Case of LCHAD Deficiency. A Comparative Study of Poland and Finland" (2016-2019) is funded by the National Science Centre in Poland (Grant No: 2015/17/B/HS3/ooro7, PI: Małgorzata Rajtar, PhD). 
in Finland ${ }^{4}$. As further ethnographic research in Finland is envisaged, in this article, I primarily scrutinise the Polish case. This project focuses on LCHAD deficiency, a rare metabolic disease. Our research is being conducted in Finland and Poland, which are both located in the Baltic Sea region. LCHADD belongs to fatty acid oxidation disorders (FAODs), which are among the most common inborn errors of metabolism. They exhibit overlapping symptoms that often occur in connection with fasting and may cause hypoketotic hypoglycemia, failure to thrive, cardiomyopathy, liver involvement and even sudden death in infancy (Fahnehjelm et al. 2016; Haglind 2016, 8-9; Immonen 2016). Additionally, LCHADD often leads to retinopathy.

After a short introduction to rare disorders, and specifically LCHAD deficiency, in the following, I juxtapose dietary treatments prescribed for this disease with state and biomedical rationalities that govern "normal" dietary patterns and normalised eating. I examine how "norms" guiding dietary treatment for patients with LCHADD are constructed and work in practice.

\section{RARE DISEASES AND LCHAD DEFICIENCY}

Rare diseases (RDs) make up a large group of diseases (up to 8,000) that are characterised by a low prevalence in populations ( $\leq 5:$ I0,000 in Europe). Nevertheless, they affect $6 \%-8 \%$ of the population during their lifetime. It is estimated that the total number of people affected by rare diseases in the EU is between 27 and 36 million (Council of the EU 2009; European Commission n.d.; EURORDIS 20I7). RDs are often severe, chronic, disabling and possibly lethal conditions; they not only decrease patients' (and their families') quality of life, but also pose a challenge for public healthcare (Libura et al. 2016; The Council of the EU 2009).

First described in 1989, LCHAD (Long-Chain 3-Hydroxyacyl-CoA Dehydrogenase) deficiency (LCHADD) is a rare, albeit life-threatening metabolic disease. It is caused by mutations in the HADHA gene, the most common being c.I528G $>\mathrm{C}$ (Immonen 2016; Piekutowska-Abramczuk et al. 2010; Sykut-Cegielska 2006). Before newborn screening for LCHADD was introduced in 2015 and 2013 in Finland and Poland respectively, the

4 This research project also attends to processes of "geneticisation" (Lippman in Heath et al. 2007, I52) and examines how people make sense of genes and incorporate them into "older" cultural categories, such as "blood" and "curse" that have been ascribed to their social and group identities, in this case the Kashubian identity. Some biomedical literature (e.g. Piekutowska-Abramczuk et al. 20IO, S373; see also Sykut-Cegielska et al. 2017, 269) argues that the prevalence of LCHADD is strongly connected with Kashubian decent. Kashubians populate Northern Poland, specifically the Pomerania region. Apart from interviews with families of LCHADD patients from this region, I8 semi-structured and/ or life history interviews with members of the Kashubian community were conducted by one of the researchers in the project (see, for instance, Kwaśniewska 20I7). 
mortality rate attributed to this disease was high; it was estimated that approximately $40 \%$ of children with LCHADD died in the early days or years of life (Autti-Rämö et al. 2005, II30). While this disease is extremely rare in Australia and Northern America ${ }^{5}$, it is relatively frequent in Europe, around the Baltic Sea in particular. More specifically, Poland and Finland probably have the highest number of LCHADD patients worldwide. In Finland, LCHADD is the most frequent mitochondrial fatty acid $\beta$-oxidation (FAO) defect. (Immonen 2016). It is worth noting that Finland has already implemented EU recommendations for establishing National Plans for Rare Diseases (Council of the EU 2009), but Poland still has not. Available data on LCHAD deficiency indicates that between 1976 and 20I4, a total of 47 patients with LCHADD were diagnosed in Finland; of those, 27 died (Immonen 20I6). In Poland, a total of 59 patients with LCHADD were diagnosed between 1986 and 2009; of these, 20 died (Sykut-Cegielska et al. 20II). In comparison, between I990 and 20I2, I6 patients were also diagnosed with LCHADD in Sweden (Fahnehjelm et al. 2016).

As is the case for other rare diseases (e.g. Featherstone and Atkinson 20I2; Larotonda 20I6; Paul and Brosco 20I3, III-I39), there currently are no drugs available that "cure" patients with rare metabolic disorders, including LCHADD. Treatment itself is clinically challenging (Haglind 2016, 9, 45; Fahnehjelm et al. 2016, I459) and it subjects patients and their family members to a dietary regimen for the rest of their lives. As Jolanta Sykut-Cegielska and her colleagues argue $(2017,266)$, when it comes to treating inborn errors of metabolism, "dietary treatment" (leczenie dietetyczne) is the right term. Dietary treatment "is based on the usage of foods in specified quantities, in specified composition, and with the addition of nutrients necessary for the organism; [it is aimed at] excluding harmful or badly tolerated [nutrients]" (Sykut-Cegielska et al. 2017, 266). For LCHADD, dietary treatment entails consumption of low-fat and high-carbohydrate foods, frequent feeding (every 3 hours for small children and every 6-8 hours for adolescents) and avoiding long periods of fasting and physical exertion (Dixon et al. 20I5; Haglind 20I6; Immonen 20I6; Sykut-Cegielska 2006). Unfortunately, adherence to this does not spare patients from hospitalisation; they are prone to episodes biomedically known as metabolic crises that may be triggered by illness, physical activity and stress, and may cause symptoms like poor feeding or loss of appetite, lack of energy and vomiting, among others. Additionally, feeding problems that often occur in children and adolescents with rare metabolic disorders

5 It is, for instance, listed in the Arizona Newborn Screening Panel that includes bloodspot screening for 28 "relatively rare," "rare" and "very rare" disorders. LCHADD is considered a "rare inherited disorder" which means that it "occurs in greater than I in 50,000 US births" (Arizona Department of Health Services n. d.). A newborn screening program has been implemented in the US since the 196os; however, individual states have been allowed to decide which conditions to screen for. By 2000 , the number of diseases screened for differed widely by state: some states (e.g. Utah) screened for 3 conditions, others for up to 36 conditions. In 2006, the American College of Medical Genetics recommended screening for 29 primary and 25 secondary conditions (Timmermans and Buchbinder 2013). 
necessitate tube feeding, which can be accomplished with devices like nasogastric or gastrostomy tubes (Rajtar 2017).

\section{NORMALISED EATING AND DIETARY GUIDELINES}

Anthropological and historical scholarship shows that dietary normalisation for children and patients has been part of state management techniques and interventions in hospitals, schools and childcare facilities dating back at least to the second half of the $18^{\text {th }}$ century (e.g. Coveney 2006; Foucault 20I4; Scholliers 20I7). For instance, according to historian Peter Scholliers $(2017,340)$ who analysed documents referencing what he called "the actual diet" in two public general hospitals in Brussels during the $\mathrm{I}^{\text {th }}$ and $2 \mathrm{O}^{\text {th }}$ centuries, "children's diets improved more rapidly than adults" due to "the paradigmatic transformation of dietetics" at that time. As a result of this transformation "children emerged as a distinct group that was readily targeted by physicians (the so-called new pediatrics)" (Scholliers 2017, 340). A similar shift occurred in other European hospitals, specifically in England, France and Germany. Scholliers further noted that hospitals throughout Europe both "increasingly" used food as a part of their treatment and commonly "wished to serve food that was similar to the fare the patients had before entering the hospital" $(2017,340)$. Dietary recommendations in hospitals were constantly scrutinised by physicians, assistants, students, nursing staff and even the patients themselves; any deviation from the dietary rules (e.g. supplying and/or eating non-prescribed food) was forbidden. These experiences were codified in the first batch of treatises published in the I88os. According to these, young patients between seven and fourteen years of age were to "receive milk, eggs, meat, rice pudding, cheese, butter, rice, bread (pain fin), potatoes, beans and peas, fruit, coffee with milk, and light beer (for poor children, lard, herring, and lots of legumineuses would replace the meat and cheese)" (Scholliers 2017, 349-350, emphasis in original). Scholliers emphasised that eggs, and particularly milk, were seen as "ideal food" for children between the ages of 2 and Io. Finally, he highlighted that beginning in the I870s, special attention was given to the diets of young hospital patients in Brussels. Along with the increased purchasing power of the working classes, this may have even transformed child nutrition outside the hospitals (among the working classes in particular). Scholliers argued that hospitals contributed to "transforming children's diet by emphasizing the consumption of milk, eggs, and wheat bread, and eating à discretion" (2017, 354, emphasis in original).

Dietary regimes of $19^{\text {th }}$ and early $20^{\text {th }}$ century Europe, as analysed by Scholliers, demonstrate a "politics of health" that involved "at least partial integration of medical practice with economic and political management, which aimed at the rationalization of society" (Foucault 20I4, II4). These dietary regulations were devised by a diverse body 
of state agents, including physicians, and were approved by municipal authorities, e.g. the Brussels city council. Occasionally, the costs of any additional food (e.g. refined bread, fresh fish, fruit, or smoked ham) were audited. The "actual diet" in the hospitals of Brussels was further evaluated by both surgeons and members of the city council. Such evaluations examined "the timetable of meals; the cooking and distribution of food; and its quantity, quality" as well as its taste. Ultimately, such evaluations revealed an "interest in food issues beyond mere cost" (Scholliers 2017, 346).

Scholliers documented dietary regimes that could be viewed as the precursors to current nutritional guidelines issued by departments or ministries of health and implemented by dietitians and health professionals. Both then and now, the "well-being" of the population, to which a panoply of management techniques has been applied, is of paramount importance to health politics and biopolitics (Foucault 1979, 20I4; see e.g. Greenhalgh 2012). As John Coveney put it,

"knowledge of the «good» diet becomes the central focus for the modern subject of food choice. As a complex form of power, nutrition became a practice of analysis, reflection, calculation and tactics on food" (Coveney 2006, 64).

Although the dietary treatments for LCHADD and other rare metabolic diseases substantially deviate from what could be considered normal guidelines, I argue that the LCHADD diet is monitored and scrutinised by dietitians and physicians in a similar way.

In the following, I present the "scientific" or "medical" model of "good nutrition" (Coveney 2006) embedded in dietary guidelines prescribed for "healthy" populations". I further address two issues that differentiate the dietary treatment for LCHADD significantly from "traditional nutritional recommendations for normal children" (Haglind 20I6, 44). These include the breastfeeding of infants and the consumption of particular fats.

\section{WHAT FOODS ARE SUITABLE FOR BABIES AND CHILDREN?}

Research in Poland has documented that the Polish Ministry of Health endorses breastfeeding, which is heralded as the "golden standard" in neonatal and baby nutrition by the European Society for Pediatric Gastroenterology, Hepatology and Nutrition (ESPGHAN), the European Food Safety Authority (EFSA) as well as the World Health Organization. (Weker and Barańska, eds., 20I4, I2; see Kramer and Kakuma 200I). Similarly, the Nordic Nutrition Recommendations (NNR) 20I2, on which

6 Beata Tobiasz-Adamczyk (2013, II-83) provides a comprehensive overview of the sociology of health and nutrition with an emphasis on the elderly and the relationship between nutrition and obesity that may be of interest to Polish readers. 
Finnish dietary guidelines are based, recommend exclusive breastfeeding "for around the first 6 months of life and partly breastfeeding until 12 months of age" (Nordic Council of Ministers 20I4, 96; 28; 85-IO2 $)^{7}$. According to these, breast milk provides the optimal nutrient combination of proteins, fats, carbohydrates and both micro and macro elements, and is thus highly beneficial for the development of infants. Ultimately, breastfeeding should constitute the sole source of food for up to 6 months. Whereas breastfeeding is recommended for babies in general, this is not the case with LCHAD deficiency (Dixon et al. 2015; Sykut-Cegielska et al. 2017, 270; interviews with dietitians). When neonatal screening yields positive test results for LCHADD, breastfeeding should be ceased because breast milk contains "bad" fats, i.e. long-chain fatty acids, which are to be avoided by anyone afflicted with this metabolic disorder. Currently, babies are typically switched to one of two powdered formulas: Lipistart ${ }^{\circ}$, a formula produced by Vitaflo (Nestlé Health Science), a UK company that produces, among others, medical foods for metabolic diseases; or Monogen ${ }^{\circledR}$, a powdered feed produced by Nutricia (Danone) ${ }^{8}$. As I was told by Ms. Kowalska, a dietitian employed by a large Warsaw hospital, both formulas are high (80\%) in MCTs (medium-chain triglycerides) and low in LCTs (long-chain triglycerides), hence they are suitable for LCHADD patients. Like MCT oil, which is equally essential in the LCHADD diet, they are available on prescription, imported via pharmacies and reimbursed by the Ministry of Health'.

7 These recommendations are often referred to as having "the scientific basis for the planning of diets for population groups and for the development of food-based dietary guidelines in the Nordic countries". They are suitable for "groups of healthy individuals and for developing national and regional nutrition policies, nutritional educational programs, food regulations, and action programmes" (Nordic Council of Ministers 20I4, 43; emphasis added). Nonetheless, they also prescribe that "for individuals with diseases and other groups with special needs, the dietary composition and energy content might have to be adjusted accordingly" (Nordic Council of Ministers 20I4, 43).

8 Both Nutricia and Vitaflo regularly sponsor events (e.g. conferences and meetings, cooking workshops, etc.) for patients, their families and physicians, which are sometimes coordinated by patient organisations. In fact, a physician told me that without such sponsors, it would be virtually impossible to hold such meetings free of charge for participants of various socioeconomic statuses. This issue is beyond the scope of this article.

9 In Finland and Poland, the costs of medicinal foods, such as infant powder formulas that contain MCTs as well as MCT oil, MCT procal, etc., that are part and parcel of dietary treatment, are reimbursed. Nonetheless, models of reimbursement in the two countries differ. Expenses above 600.00 EUR/year are reimbursed in Finland, however parents still pay a nominal fee of 2.50 EUR per can. In Poland, once their application for reimbursement is approved by the Ministry of Health, parents pay a nominal fee of 3.20 PLN (less than I.oo EUR) per can. The "Polish model" has been much more frustrating to parents and patients as well as more time-consuming for medical personnel than for their Finnish counterparts. In order to ensure that patients have uninterrupted access to these products, parents are required to regularly- every 3 months on average - apply to the Ministry of Health for reimbursement. 
Breastfeeding is a source of concern that compounds the stress LCHADD parents endure. For one Polish mother I spoke with, breastfeeding her infant had never even been an option. Later in infancy, her child was diagnosed with LCHADD. She told me, "now they're saying that breast milk should not have been recommended after all. And bitterly, she reflected,

"Well, now some are saying that we are bad mothers because we don't breastfeed, we don't want [to breastfeed], but, well ... sometimes you can't. You just can't".

In another instance, a newborn had been screened before LCHADD was added to the newborn screening panel; subsequently, it was diagnosed in light of a metabolic crisis. Her mother, who had breastfed up to the time of diagnosis, spoke of the practice with regret:

"If I were on a diet during my pregnancy, nothing would have happened. If I had known that she was already sick when she was in my belly... But who could have known that? I harmed her because I was breastfeeding her; my milk was fatty. Well, unfortunately, I harmed her”.

Over tea in her office, Ms. Kowalska provided me with a thorough overview of the diet she prescribes for her patients; she even delved into the specifics of individual cases.

"This diet [she began] may be diversified (rozszerzana) according to the dietary guidelines (schemat żywenia) for healthy children. (...) [She further continued:] Starting from 6 months of age we introduce mashed vegetables and mashed fruits, including mashed vegetables with meat, but we emphasize that this must be the leanest meat possible".

With the exception of breastfeeding, these recommendations follow the dietary guidelines for "normal" children which suggest that

"from 6 months of age, the gradual introduction of a diversified diet is recommended. Breast milk as a part of the diet is recommended throughout the child's first year, and partial breastfeeding can be continued for as long as it suits the mother and child" (Nordic Council of Ministers 20I4, 98; see also Szajewska 20ı7).

Ms. Kowalska gives her patients (or the parents of infants and small children with LCHADD) a list of allowed foods that includes, among others, chicken or turkey breast, and low-fat fish or egg whites, all of which provide the required dietary protein $^{10}$. The youngest patients as well as those with nasogastric and gastrostomy tubes should still be fed with powdered formula. Expanding the diet means, as the dietitian

Io Patients and/or their parents receive special charts showing allowed and forbidden foods. In Poland, these charts are often produced by Nutricia, a Dutch company that specialises in products for babies, including clinical nutrition for babies with inborn errors of metabolism, among others. Nutricia produces, for instance, MCT oil that is required in the diet of LCHADD patients. 
explained to me, reducing the powdered formula enriched with MCT. In its stead, MCT oil itself must be introduced into the diet. The amount of MCT oil (or MCT ProCal powder) to be consumed depends on the patient's age, test results and dietary guidelines for the general population regarding what Ms. Kowalska and other physicians termed "classic fat".

The problem with the "classic" fat found in most vegetable oils, butter (and many dairy products), red and fatty meats, fatty fish and some fruits and vegetables (e.g. avocados and olives) is that it contains long-chain fatty acids that should not be consumed by LCHADD patients, but are of value to healthy individuals. Highlighting "strong scientific evidence", the Nordic Nutrition Recommendations 20I2, for instance, emphasise the consumption of

"plant foods such as vegetables, fruits and berries, nuts and seeds, and whole-grain cereals [that] are rich in dietary fibre, micronutrients, and potential bioactive constituents".

Such a diet should also include

"fatty fish, nuts, seeds, and vegetable oils [that] provide different kinds of unsaturated fatty acids. Seed oils such as rapeseed and flaxseed oils are rich in both n-3 and n-6 fatty acids. The very long-chain n-3 fatty acids found in fish are of special health importance" (Nordic Council of Ministers 20I4, 2I-22).

Additionally, the NNR 2012 warn against "high consumption" of beverages with added sugars, refined grains (i.e. white bread and products made with sifted flour), sweets, sugar-rich drinks and desserts. Generally, among its recommendations to "promote health and wellbeing among the Nordic populations", the NNR 2012 encourages individuals to "decrease energy density, increase micronutrient density, and improve carbohydrate quality" (Nordic Council of Ministers 2012, 22; emphasis in the original). This goal should be achieved by following diets based on "naturally fibre-rich plant foods" that are generally lower in energy density than those dominated by animal foods. Products high in added sugar or refined grains that are high in energy density should not be consumed as they are linked to increased risk of a number of chronic diseases, such as diabetes. Unable to consume "classic" fat, but in need of products that are high in energy density, LCHADD patients, however, have to consume low-fat sweets (such as candy, Haribo jellies, jelly beans, etc. that contain o\%-I\% fat) and starchy foods (often potatoes, breads and cornstarch before both exercise and sleep) in quantities that far exceed the above recommendations. One mother, for instance, told me that her teenager consumes up to one kilogram of Haribo-like jellies daily.

Ms. Kowalska recounted her individual crucible: accommodating the requests of one of her patient's mothers. According to her, "there are some schematic ways of thinking that parents use". She continued: "To them, it is common knowledge that children eat sausages (parówki). Or that children like sweets or children don't like vegetables". Drawing from her research on children and food in Warsaw, Zofia Boni noticed that 
"ideas about, and practices of feeding might and often do differ from those about eating, and vice versa" (2018, 107). Locked into "schematic ways of thinking" about foods "suitable" and "liked" by children that are often perpetuated by the advertising industry, the mother was convinced that children absolutely have to eat sausages. Even the leanest links, however, are not suitable for LCHADD children due to their fat content; thus, the dietitian was strongly opposed to her patients consuming them. Despite this, the obdurate mother persisted, still demanding a recipe. Finally, they concocted a recipe for home-made sausages that would contain a permissible amount of fat, but at the same time resemble the food item that "normal" children allegedly love.

"It does not taste like a classic sausage of course - the dietitian conceded - but it provides some [food] variety for the kid. So if the mother is willing to make such a meal, why not?".

This dietitian belongs to the highly creative individuals who work at (university) hospitals in Finland and Poland. It is evident in the "recipe for sausages" example that such dietitians try to accommodate the wishes of patients and their parents while still holding true to the dietary guidelines for a specific disorder. Some parents prefer such an attitude over what they called an "overly textbook approach" (strasznie ksiażkowo podchodzi) and - informed by experience, no doubt, - know that one square of chocolate or even one cookie should not be cause for concern. Others, however, favour the more legalistic or "strict" dietitians that would rebuke them for even the slightest dietary transgression. Nonetheless, the dietitian's role in treatment success is to manage the well-being of their patients by scrutinising what foods are consumed and how often their patients eat and/or are fed:

"to devise the appropriate diet; to evaluate menus; to monitor the implementation of dietary recommendations, and to identify nutritional issues" (Sykut-Cegielska et al. 2017, 266-267).

Along with "regular monitoring" of dietary treatment, dietitians are also responsible for "training parents of the sick child in nutrition, [especially] in case of an acute metabolic decompensation" (Sykut-Cegielska et al. 2017, 267).

\section{MONITORING AND SELF-SURVEILLANCE}

Monitoring plays an important role in the biomedical management of rare metabolic disorders, such as LCHADD, as well as in (self-)surveillance that is intended to police the body, especially the eating body (e.g. Kimura et al. 2014; Trainer et al. 2017; Tobiasz-Adamczyk 2013, 63-77; Yates-Doerr 2013). The introductory chapter to Clinical Paediatric Dietetics emphasises that the "assessment and monitoring of nutritional status should be included in any dietary regimen, audit procedure or research project where a modified diet has a role" (Shaw and McCarthy 2015, 3). Clinical Paediatric 
Dietetics (Dixon et al. 2015) distinguishes three kinds of monitoring: clinical, biochemical and dietary. While clinical monitoring ${ }^{11}$ measures the weight, growth and development of patients' bodies; biochemical monitoring focuses on the measurement of acylcarnitines, fat soluble vitamins and so on. Both should assess adherence to or deviation from established norms, either concerning bodily development or the "nutritional adequacy of the diet" (Dixon et al. 2015, 607). Of course, the latter plays an important role in dietary monitoring. However, the notion of "dietary monitoring" far exceeds both the measurement of nutrients in the patient's diet and the focus on the individual body. Here, families, and specifically parents, enter into the picture as those who "need continued support and advice" once an infant or child is "established on dietary treatment" (Dixon et al. 2015, 606). Moreover, regular dietary monitoring encompasses not only diet-related issues, such as making sure that "the overnight feeds provide adequate $\mathrm{CHO}$ (or energy) for age" or checking "the intake of long and medium chain fat" (Dixon et al. 2015, 606). "Support and advice" offered to parents within this regime requires providing "new ideas and information on low fat manufactured foods" (Dixon et al. 2015, 606).

While clinical and biochemical monitoring can be carried out regularly in a clinic (every 3 to 6 months depending on the patient's age and health condition), dietary monitoring is more difficult to conduct even if physicians and dietitians argue that these test results ultimately show whether a patient is following dietary guidelines. One established way of dietary monitoring is the "food diary".

Prior to check-ups, parents are requested to keep a detailed record of all items (including the brand names of food products) their kids have consumed in the past $2-3$ days. The food diary is subsequently presented for inspection during their checkup. However, as the mother of a primary school pupil in Poland told me, keeping a food diary is pointless for her because her child perpetually consumes a diet consisting of the same items. Nonetheless, she still begrudgingly complies, however redundant it may feel to her.

Food diaries exemplify (self-)surveillance that instills (self-)discipline, responsibility and medical adherence (Kimura et al. 20I4; Trainer et al. 2017). According to Kimura and her colleagues "documenting eating habits puts the eater in the position of understanding their health as a scientific project, and of having to explain deviant data points as bad behavior" (20I4, 38). Though some parents question the necessity and purpose of conducting food diaries, they nonetheless strictly adhere to quantities and metrics while applying MCT oil and other nutriceuticals or functional foods

II Other authors in this volume put "clinical monitoring" into the "clinical assessment" category. The latter "involves a medical history and a physical examination. The medical history will identify medical, social or environmental factors that may be risk factors for the development of nutritional problems. Such factors may include parental knowledge and finance available for food purchase, underlying disease, treatments, investigations and medications" (Shaw and McCarthy 20I5, 7). 
(Dumit 20I2; Scrinis 2013) into their kids' frequent meals, even employing a syringe for more accurate and precise measurement.

\section{CREATING NORMS IN PRACTICE}

In a survey conducted among US metabolic dietitians on "nutritional strategies" utilised in the treatment of fatty acid oxidation disorders (FAODs) (including LCHADD), Solis and Singh (2002, 1800) emphasised that medical nutrition therapy is considered a "standard treatment for FAODs". They determined, however, that along with "diverse approaches used to manage" FAODs, there was "a lack of evidence supporting the protocols in use; and a need for comprehensive, clinical research studies to determine optimal, patient care". The survey showed, among others, that there were no uniform recommendations regarding the frequency of meals (ranging from 2-4.4 for infants and 3-7 for children with LCHADD). Neither was there agreement regarding an "optimized" fat intake for each disease, i.e. the percentage of dietary fat for LCHADD patients ranged between IO\% and 33\%. Authors strongly advised "the development of standardized treatment and monitoring strategies and product formulations tailored to the needs" of LCHADD patients (Solis and Singh 2002, I803).

I am not sure if my interviewees were versed in the Solis and Singh article, but they certainly raised the same concerns regarding the lack of standardised dietary treatment for LCHADD patients. Popular and derogatory usage characterizes standards and standardisation as homogenising and dehumanising, and as such, they are contested (see e.g. Timmermans and Epstein 20I0; Yates-Doerr 2013). Nonetheless, my interviewees believed - although "hoped" may be a better term - that standards may "provide the optimal technical solution for particular problems" (Timmermans and Epstein 20I0, 73-74), such as the percentage of dietary fats to allow in the LCHADD diet. Thus, they would probably agree with Stefan Timmerman and Steven Epstein who define standardisation "as a process of constructing uniformities across time and space, through the generation of agreed-upon rules" (20IO, 7I). This does not mean, however, that standards would not be subject to change. Just the opposite, standardisation "is an active process that aspires to stability and order" (Timmermans and Epstein 20I0, 84; see Yates-Doerr 20I3, 284). When I asked Ms. Kowalska about the "norms" she follows for designating the percentage of MCT oil to be consumed for energy intake, I was surprised by her response:

\footnotetext{
"They [the norms] come from above (odgórnie ustalane) and are repeated by many associations, at many conferences. But I know that there are differences too. Every country has its customs so to speak. According to our norms, the percentage amount of MCT fat is to constitute IO- $20 \%$ of dietary energy [intake]. Classic fat can account for up to IO\%, so if we combine both fats together, the fat norm would not cause any deficiencies. The only deficiencies it could cause regard fat soluble vitamins
} 
because MCT only carries energy, but no vitamins. So, vitamins are supplemented. (...) According to American norms, however, MCT fat can go up to $24 \%$ [of energy intake]. I heard somewhere that if you exceed $20 \%$, it [MCT] can be transformed into long chain fats that are toxic, so there shouldn't be more than $20 \%$. To tell you the truth, opinions differ. We stick to IO-20\%”. (see also Sykut-Cegielska et al. 2017, 270).

In light of the varying expert opinions and lack of global standards, the ultimate criterion for truth and validity for the norms she has been following is the health of her patients. She argued "I prefer to utilise our [norms] because our patients are well balanced (dobrze wyrównani), they have good results, so I don't see any point in changing anything".

Not only physicians and dietitians in countries like Finland and Poland have to balance the health of their patients against elusive "norms". A close reading of the "bible" of metabolic disorders mentioned earlier in this paper: Clinical Paediatric Dietetics shows that the seemingly authoritative voice present in the volume is constantly undermined by phrases that expose the lack of sufficient knowledge for determining optimal amounts of certain nutrients. Here are some examples that refer to dietary treatment of FAODs, particularly LCHADD:

\footnotetext{
"Treatment recommendations have been published for $\beta$-oxidation defects based mainly on expert opinion from a European workshop. (...) The safe upper limit for long chain fat intake is unknown and varies with the severity of the disorder. (...) For severe defects of LCHADD and MTPD it is recommended to restrict LCT [Long chain triglycerides] to as low as practically possible $(5 \%-10 \%$ energy intake). (...) It has been suggested that patients should maintain a high intake of MCT [Medium chain triglycerides] throughout life (IO\%-20\% energy intake). [However] ( $\mathrm{t}$ )he optimal amount or ratio of C8, Cio fatty acids to provide is not known".
}

Finally, the same text admits that long-term usage of MCT "in humans has never been systematically studied, so it is not known if there are any detrimental effects" (Dixon et al. 2015, 596). Additionally, despite general agreement on the necessity of frequent feeding in LCHADD and some other FAODs, "the safe duration of fasting for different disorders and ages has not been well-defined and practices differ between countries and centres" (Dixon et al. 20I5, 598). Neither is there agreement on overnight feeding: "In the USA no consensus on overnight feeding could be reached by an expert panel". In the UK, however, "children with severe defects are fed 3-4 hourly during the day and by continuous nasogastric or gastrostomy feeding overnight (or the child is woken for feeds during the night)" (Dixon et al. 2015, 598). Nonetheless, overnight feeding "is not standard practice" (Dixon et al. 2015, 598). It is worth emphasising that all parents we have spoken to in Finland and Poland practiced (and were obliged to practice) overnight feeding of their kids.

Unlike national and international dietary guidelines for "healthy" individuals that reference a "scientific basis" and "scientific evidence", dietary treatment of rare 
metabolic disorders, such as LCHADD, is primarily based on the personal experiences of physicians and dietitians along with "expert opinion" (see Timmermans and Epstein 20IO, 8I).

\section{CONCLUSION}

A decade ago John Coveney (2006; see Scrinis 2013) noted that public health nutrition has become rife with tension when it comes to the ideology of health promotion, which he argued, oscillates between medical/scientific and social/community models. Despite the differences between these two models, they are similar when it comes to what they consider to be "good" food and nutrition. As he puts it,

"in each, the subject, or the collective subject (the community) is required to be self-reflexive and self-regulating in order to make "proper» and informed decisions" (Coveney 2006, 19).

Dietary guidelines in Finland (and Nordic countries in general) and Poland for "healthy" individuals subscribe to the scientific model in which

"individuals are required to make informed choices about their eating habits after having learned and considered the scientific facts about food and health" (Coveney 2006, I8; see Yates-Doerr 2013 for Guatemala).

Moreover, such guidelines operate on the premise that healthy individuals are willing and able to eat, in other words, that eating is a "norm". By calling for the "adjustment" of dietary recommendations for individuals with diseases (Nordic Council of Ministers 20I4, 43), however, public health authorities implicitly require not only healthy individuals to be "self-reflective, self-regulating individual(s) with the correct concern for themselves" (Coveney 2006, I8). This medical model extends to rare metabolic disorders, fully disregarding the paucity of sufficient scientific knowledge concerning both rare diseases and the results of dietary treatment. Additionally, infants and children with LCHADD commonly face feeding problems and are regularly fed through nasogastric or gastrostomy tubes for months, if not years of their lives (Rajtar 2017). Faced with insufficient "scientific evidence" (e.g. random control trials) and lacking in global standards, physicians and dietitians treat "norms" as "tools" that are to be translated into dietary practices based on their own personal experience, expert opinion and patient test results. These dietary recommendations are further appropriated by both parents and the patients themselves, who cannot or would not follow them to the letter. 


\section{BIBLIOGRAPHY}

Arizona Department of Health Services. n.d. Arizona's Newborn Screening Panel. http://www.azdhs.gov/ preparedness/state-laboratory/newborn-screening/index.php?utm_source=TWITTER\&utm_ medium=AZDHS\&utm_campaign=Newborn\%20Screening\&utm_content $=585776584 \&$ linkId $=2888089 \mathrm{I} \#$ info-for-parents-disorder-info. Access: 03.08.2018.

Autti-Rämö I., Mäkelä M., Sintonen H., Koskinen H., Laajalahti L., Halila R., Kääriäinen H., Lap a t to R., Näntö-Salonen K., Pulkki K., Renlund K., S a lo M., Tyn i T. 2005. Expanding screening for rare metabolic disease in the newborn: an analysis of costs, effect and ethical consequences for decision-making in Finland. Acta Paediatrica 94, II26-II36.

B o n i Z. 20I8. "My mum feeds me, but really, I eat whatever I want!" A relational approach to feeding and eating. In V. Hartman, Cappellini B., Faircloth Ch. (eds.), Feeding Children Inside and Outside the Home. Critical Perspectives. Routledge, I07-I23.

Council of the EU. 2009. Council recommendation of 8 June 2009 on an action in the field of rare diseases (2009/CI5I/02). http://eur-lex.europa.eu/LexUriServ/LexUriServ.do?uri=OJ:C:2009:151:0007:00I o:EN:PDF. Access: 03.08.2018.

C ove n e y J. 2006. Food, morals and meaning. The pleasure and anxiety of eating. London, New York.

Dixon M., Stafford J., White F., Clayton N., Gallagher J. 20I5. Disorders of mitochondrial energy metabolism, lipid metabolism and other disorders. In V. Shaw (ed.), Clinical paediatric dietetics. Chichester, UK, 588-636.

D u m i t J. 2012. Drugs for life. How pharmaceutical companies define our health. Durham, London.

European Commission. n.d. Rare diseases. https://ec.europa.eu/health/non_communicable_diseases/ rare_diseases_en. Access: 03.08.2018.

Fahnehjelm K.T., Liu Y., Olsson D., Amrén U., Haglind Ch.B., Holmström G., Halldin M., Andreasson S., Nordenström A. 20I6. Most patients with Longchain 3-hydroxyacyl-CoA dehydrogenase deficiency develop pathological or subnormal retinal function. Acta Paedriatica I05, I45I-I460.

$\mathrm{Fe}$ atherstone K. and Atkins on P. 20I2. Creating conditions. The making and remaking of a genetic condition. London, New York.

F o u ca ult M. 1979. The will to knowledge: The history of sexuality. Vol. I. London.

Fou cault M. 20I4. The politics of health in the eighteenth century. Foucault Studies 18, II3-I27.

Green halgh S. 20I2. Weighty subjects: the biopolitics of the U.S. war on fat. American Ethnologist 39 (3), $47 \mathrm{I}-487$.

$\mathrm{H}$ a $\mathrm{g}$ ind Ch. B. 2016. Energy metabolism and clinical symptoms in beta-oxidation defects, especially Long-chain 3-hydroxyacyl-Coenzyme A dehydrogenase deficiency. PhD manuscript. Karolinska Institutet, Stockholm.

Heath D., Rapp R., Taussig K.-S. 2007. Genetic citizenship. In D. Nugent and J. Vincent (eds.), A companion to the anthropology of politics. Malden, MA, I52-167.

I $\mathrm{m}$ m o $\mathrm{n}$ e n T. 2016. Long-chain 3-hydroxyacyl-CoA dehydrogenase deficiency in Finland-earlier diagnosis and strict diets improve the survival rate and clinical course. $\mathrm{PhD}$ manuscript. Helsinki University Hospital, University of Helsinki.

Kimura A. H., Biltek off Ch., Mudry J., Hayes-Conroy J. 20I4. Nutrition as project. Gastronomica. The Journal of Critical Food Studies I4 (3), 34-45.

$\mathrm{K} \mathrm{r}$ a m e r M.S. and Ka k u m a R. 200I. The optimal duration of exclusive breastfeeding. A systematic review. Geneva: World Health Organization (WHO/NHD/oı.o8). http://www.who.int/nutrition/ publications/optimal_duration_of_exc_bfeeding_review_eng.pdf. Access: 03.08.20I8. 
Kwaśn i ewska A. 20I7. Choroba genetyczna jako klątwa. Analiza i kontekst dyskursu medialnego dotyczącego tzw. genu kaszubskiego [Genetic Disease as a Curse: An Analysis and Contextualization of the media Discourse in the "Kashubian Gene"]. LUD IOI, 23I-252.

La rotonda A. 2016. Experiencing rare diseases. In L. Manderson, E. Cartwright and A. Hardon (eds.), The Routledge Handbook of medical anthropology. New York, 26-3I.

Libura M., Władusiuk M., Małowicka M., Grabowska E., Gałązka-Sobotka M., Gryglewic z J. 2016. Choroby rzadkie w Polsce. Stan obecny i perspektywy. Warszawa.

Nordic Council of Ministers. 20I4. Nordic nutrition recommendations 20I2. Integrating nutrition and physical activity. Copenhagen. Available at: https:/www.norden.org/en/theme/former-themes/ themes-2016/nordic-nutrition-recommendation/nordic-nutrition-recommendations-20I2. Access: 03.08.2018.

Pa ul D. B. and B rosco J. P. 20I3. The PKU paradox. A short history of genetic disease. Baltimore.

Piekutowska-Abramczuk D., Olsen R.K.J., Wierzba J., Popowska E., Jurkiewicz D., Ciara E., Ołtarzewski M., Gradowska W., Sykut-Cegielska J., Krajewska-Walasek M., Andresen B.S., Gregersen N., Pronicka E. 2010. A comprehensive HADHA c.I528G $>$ C frequency study reveals high prevalence of Long-chain 3-hydroxyacyl-CoA dehydrogenase deficiency in Poland. Journal of Inherited Metabolic Disease 33 (Suppl. 3), S373-S377.

Rajt a r M. 20I7. On (nie)naturalności jedzenia. Pokarmy i technologie biomedyczne w chorobach metabolicznych [On the (Un)Naturalness of Eating: Foods and Biomedical Technologies in Metabolic Disorders]. LUD IOI, 383-400.

Scholliers P. 20I7. Norms and practices of children's diets in Brussels hospitals, I830-1914. The Journal of the History of Childhood and Youth ro (3), 339-36r.

$\mathrm{S} \mathrm{cr}$ in is G. 2013. Nutritionism. The science and politics of dietary advice. New York.

$\mathrm{S}$ h aw V. (ed.) 20I5. Clinical paediatric dietetics. Chichester, UK.

$\mathrm{Sh}$ aw V. and McCarthy H. 20I5. Nutritional assessment, dietary requirements, feed supplementation. In V. Shaw (ed.), Clinical paediatric dietetics. Chichester, UK, 3-22.

S o l i s J. O. and Sing h R. H. 2002. Management of fatty acid oxidation disorders: a survey of current treatment strategies. Journal of the American Dietetic Association 102 (I2), I800-1806.

S y k u t-C e gi elsk a J. 2006. Mitochondrialne zaburzenia utleniania kwasów ttuszczowych. Badania kliniczne, biochemiczne i molekularne u polskich pacjentów [Mitochondrial fatty acid oxidation disorders: Clinical, biochemical and molecular tests on Polish patients]. Manuscript of postdoctoral dissertation. Warszawa.

Sykut-Cegielska J., Kowalik A. and Giżewska M. 20I7. In H. Szajewska and A. Horvarth (eds.), Żywienie i leczenie żywieniowe dzieci i mtodzieży. Cracow: Medycyna praktyczna, 264-286.

S z a jewska H. 20I7. Wprowadzanie pokarmów uzupełniających. In H. Szajewska and A. Horvarth (eds.), Żywienie i leczenie żywieniowe dzieci i mtodzieży. Cracow: Medycyna praktyczna, 46-48.

Ti m mermans S. and B u ch b ind e r M. 2013. Saving babies? The consequences of newborn genetic screening. Chicago.

Ti m mermans S. and Eps te in S. 20Io. A world of standards but not a standard world: towards a sociology of standards and standarization. Annual Review of Sociology 36, 69-89.

To b i a s z- A d a m c z y k B. (ed.) 20I3. Od socjologii medycyny do socjologii żywienia. Cracow: Jagiellonian University Press.

Traine r S., Wutich A., B rew is A. 20I7. Eating in the Panopticon: surveillance of food and weight before and after bariatric surgery. Medical Anthropology 36 (5), 500-5I4. 
Weke r H. and B a rańska M. (eds.) 20I4. Żywienie niemowląt i matych dzieci. Zasady postępowania $w$ żywieniu zbiorowym [Nutrition of babies and small children. Dietary Guidelines]. Warszawa. http://www.imid.med.pl/images/do-pobrania/Zywienie_niemowlat_www.pdf. Access: 20.II.20I7.

Yates-D o e r r E. 20I3. Complex carbohydrates: on the relevance of ethnography in nutrition education. In E-J. Abbots and A. Lavis (eds.), Why we eat, how we eat: contemporary encounters between foods and bodies. Farnham, 27I-286.

\section{Author's address}

Małgorzata Rajtar PhD. Hab.

Institute of Philosophy and Sociology

Polish Academy of Sciences [PAN]

ul. Nowy Świat 72, o0-330 Warszawa, POLAND

e-mail: mrajtar@ifispan.waw.pl

ORCID: 0000-0002-3807-I547 
